\title{
Directive Speech Acts in the Poems of Lanang Setiawan, A local Poet of Tegal
}

\author{
mualimin mualimin ${ }^{1}$, dwi wulandari ${ }^{2}$ \\ \{mualiminischaqfibundip@gmail.com ${ }^{1}$, wulandaridwi76@gmail.com²
}

Department of English, Faculty of Humanities, Diponegoro University

Jl. Prof. Soedarto, S.H. Undip Tembalang, Semarang, Central Java - Indonesia, 50275

\begin{abstract}
Poems can be used to express the writer's response to the issues emerging around his social life. This paper aims at finding out how the language is used in the poems of Lanang Setiawan in Javanese of Tegal. The source of the data is three collections of his poems entitled Tegal Sumbu Pendek, Tegal Melawan and Ndoro Binyak. The colleted data are in the forms of utterances analyzed based on speech act theory proposed by some experts. The finding shows that directive speech acts in the poems are realized both directly and indirectly. The direct directive speech acts are expressed in the forms of imperative sentences, while the indirect directive spech acts are realized in the form of declarative sentences with the expression of need, desire, and expectation. The factors influencing the directness of the directive speech acts are the distance and power between the speakers and the hearers.
\end{abstract}

Keywords: Literary work; directive speech act; Javanese of Tegal.

\section{Introduction}

Javanese of Tegal dialect, more commonly called Tegal dialect, is one of the Javanese dialects used by the people living in Tegal City and Tegal Regency and the area adjacent to the two regions, namely Brebes Regency, Pemalang Regency. In addition, Tegal dialect is also used by Tegal people who migrate or settle in other areas spreading across various regions in Indonesia. According to statistics[1][2], the residents of Tegal City and Tegal Regency amounted to 262,127 and 1,392,260 people respectively.

Tegal dialect is used by more than one million five hundred thousand speakers. The research on the use of Tegal dialect, however, has not much been carried out.This study examines the use of directive speech act in Javanese of Tegal used in poems written by a local writer, Lanang Setiawan. As a writer, he is quite well-known in the literary community in Tegal City. As a local writer, Setiawan has written a lot of literary works, both in the form of poetry, novels, and dramas both in Indonesian and also in Javanese of the Tegal. Because of his efforts, Setiawan was awared the Rancage Award in 2011.

Some experts and researches have been involved on similar topics. The following experts [3][4][5][6].have discussed directives speech acts. Other reseachers have carried out research on the topic[7][8][9] and some researches have also had Javanese as the object of their study[10][11][12]. As far as the author's knowledge, pragmatic research with the object of Tegal dialect is still very little. For this reason, the author feels the need to conduct this research in to enrich the Javanese pragmatic research, especially the Tegal dialect.

This research focuses on the realization of directive speech acts used in Lanang Setiawan's poem collected in three poetry anthologies as mentioned above formulated as 
follows: 1) how directive speech is realized in the poems, 2) what factors influence the directive utterance.

Speech acts theory was first put forward by the Austin[3]in 19 62. Austin idea was later developed by Searle[4] (1972) which states that speech acts can be classified into five, namely assertive or representative speech acts, directive speech acts, expressive speech acts, commissive speech acts, and declaration speech acts. Directive speech act, the topic of this research, is one of the types of speech acts in which the speaker has an intention that the hearer is to take action as stated in the utterance.

Edmonson and House as cited by Aijmer[5], added that in request, the actions intended are the speakers' interests which is more beneficial for the speaker than the hearer. This request speech act is different from suggestion which is more beneficial for the haerer. Trosborg[6] added that the exposition of requests was carried out before the event (pre-event) while complaining is said after the event (post-event).

Directive speech acts can be expressed directly or indirectly. An example of directive speech act expressed directly in Tegal dialect is "Tulung, jukutna bukune nyong ning meja! " Please, get my book on the table. ' The utterance is called direct because the use of imperative is indeed to instruct the speaker to take action. In every day life, however, directive speech acts are also expressed indirectly. An example of indirect directive speech act is the utterance “ Rika duwe dhuwit, Kang?' Do you have money, brother?' It is called an indirect speech because the form of the utterance is questioning while the intention of the speaker, is requesting some money.

According to Searle[4], there are more than five kinds of utterances that are conventionally used to realize directive speech acts indirectly, namely through utterances in relation to the speaker's ability, wishes or desires, the desires or willingness of the addressee to take action, the reason for the need for an action, and utterance which is a combination of several utterances and incorporation of explicit directive illocutionary verbs with one of the groups above.

\section{Method}

The data of this research are directive utterances found in three Tegalan poetry anthologies by Lanang Setiawan entitled Tegal Sumbu Pendek [13]), Tegal Melawan[14]) and Ndoro Binyak [15] There are 26 poems selected randomly; those are 6 poems from [13], 11 poems from [14], and 9 poems from 15]. Data collection is carried out by examining each directive utterance speech found in the poems. Each utterance having illocucionary act of directive is then identified and classified by taking into account the context and situation of the utterance. Data analysis was carried out inductively The collected data are then examined more closely with regard to the factors that influence the use of directive utterance in the poems.

\section{Results and Discussion}

\subsection{Types of Directive Utterance Found in Lanang Setiawan's Poetry}

The directive speech acts found in the Lanang Setiawan's poem include both direct and indirect directive utterances as seen in the following table. 
Table I. Types of Directive Utterance found in Lanang Setiawan's Poems

\begin{tabular}{clcc}
\hline No & Type of Directive Utterance & Amount & \% \\
\hline 1 & Direct utterance & 37 & 78 \\
2 & Indirect utterance & 10 & 22 \\
\hline & Total & 47 & 100
\end{tabular}

According Table 1 above, it can be seen there are as many as 37 utterances (78\%), or more than two-thirds of directive speeches are expressed directly, and only 10 utterances $(22 \%)$ or about one third are expressed indirectly.

Some examples of directives speech acts expressed directly can be seen in the followings: (1) Dadia wong nomer siji, aja dadi nomer loro. 'Be number one, don't be number two'; (2) Tulung, aja tembenglar, aja gawe ewonan rakyat keler-keler. 'Please, don't be ignorant, don't frustrate thousands of people'.

In the above utterances, directive utterances are expressed directly using imperative sentences. In Javanese, the imperative utterance is indicated by the addition of the $-a$ suffix in the word dadi into dadia as found in utterance (1). The addition of sound $-a$ in the word indicates that the sentence is a command sentence or imperative categorized as direct directive speech. In addition to the positive form of imperative, in the data above there is also negative imperatives, or prohibiting as found in utterances (1) and (2). In the utterances there is a word aja 'do not' as in the utterance of aja dadi nomer loroand aja tembenglar.

In addition to direct utterances, in the poems are also found indirect directive utterances as seen below: (3) Kekuasaan pancen butuh musuh. 'Power does require enemie; (4) Kanggo dheweke, poliandri dadi impiane. 'For him, polyandry is a dream' (5) Lan enyong ngenteni kiprahe kowen. 'And I'm waiting for your efforts' in the utterances from (3) to (5), directive speech acts are expressed indirectly. In utterance (3) the directive utterance is expressed by the use of the word butuh in the utterance. Furthermore, in utterances (4) and (5), directive speech acts are also indicated indirectly by expressions of desire, namely the word impiane 'dream' in utterance 4), the word ngenteni 'waiting for' in utterance (5).

\subsection{Factors Infleuncing the Forms of Directive utterances}

To know the factors influencing directive speech acts, it is necessary to describe the setting. As mentioned earlier, when these poems were written, the socio-political situation in Tegal City was in disharmony, especially between the Mayor of Tegal, Mashita, and her subordinate officials including the Deputy Mayor. This situation prompted Lanang Setiawan to make some efforts through literary works.

Based on the background, basically there are two social factors that influence the forms of directive speech acts found in Lanang Setiawan's poems, namely power and distance. As a resident Lanang has less power than the Mayor, who is the head of the region. The Mayor has a role as a parent of all citizens. As a Javanese, when writing poetry, Lanang Setiawan should use the utterances showing respect to the Mayor. In this kind of situation, Lanang Setiawan should use krama instead of ngoko variant to show respect. In fact, Lanang Setiawan, mostly use ngoko language. The choice of this variant may indicate that Lanang Setiawan wants to show his feeling of anger. By writing the poems, he is trying to insult the mayor in purpose in the hope that the mayor will be aware of her fault. 
In some poems Lanang Setiawan also uses terms of addresss showing as if he were her child by using the word Mane 'my mother'. It means that Lanang Setiawan considers the mayor as his parent and sometimes he also uses the utterances without mentioning the addressee. The latter tends to be directed toward common people, not to a certain person. In this situation, the utterances are not addressed directly to the mayor. In such a situation it cannot be said that speaker has higher power than the hearer or vice versa. This situation can be seen from the utterances below: 7) Mane wong wadon, donge nganggo surasa.' Mom, as a woman you should think of your feeling'; (8) Kaeh delengen Mane. 'Look at that, Mom'; (9) Eling Mane: utang pati nyaur pati.'Remember My Mom: death is answered by death'.

In the utterances above, Lanang Setiawan uses ngoko variant, a variant of Javanese that is usually used for people who are in equal status. In utterance 7), 8), and 9), Lanang uses terms of address Mane 'mother' referring to the mayor. It means that he considers that the mayor is his mother and in Javanese it is considered inappropriate talking to someone with higher status or older using ngoko instead of krama. In addition to power factors, social distance also appears in data 7), 8) and 9). In these data the author uses the word Mane 'mother' which also shows how the speaker considers the mayor as someone who has a close person or is a family member, namely as the mother. In other words, the close relationship between the speaker and the hearer influences the choice of language variant.

When the speaker writes utterances directed to common people, other than the mayor, the speaker tends to reveal the utterances of directives in the forms of invitation as seen in the following utterances; (10) Takjaluk sedulur-sedulure enyong gemredeg maju maring gelanggang laga. I request you all of my relatives to come to the arena for fighting; (11) Aja mangmang aja bimbang, nglawan penguwasa maksiat. 'Don't hesitate, don't be afraid of fighting against the immoral ruler.'

In utterances (10) and (11) the poet uses directive speech in the form of invitation to others to fight against the mayor. This means that what was done by the mayor at that time was considered out of conduct, so the people needed to do something to change the administration of Tegal Muncipality.

\section{Conclusion}

Based on the discussion above, it can be concluded that directive speech acts in Lanang Setiawan's poems are expressed both directly and indirectly. The direct one by using imperative, while indirect speech act is expressed by declarative sentences. There are two factors influencing utterances, namely the power and distance. Based on the power factor, the poet does not consider the mayor as his boss who needs to be respected because he feels that the ruler has done something not appropriate. In terms of social distance, the speaker also considers the mayor as a close person indicated by the use of the word Mane ,mother'. When referring to people other than the mayor, the speaker considers them as friends or persons with equal status.

\section{Acknowledgements}

The writer would like to extend his gratitude to the Dean of the Faculty of Humanities, Universitas Diponegoro who has provided the research fund. The writer would like express his appreciation to Lanang Setiawan who has wiritten antologies as the data source for this research. 


\section{References}

[1]BPS Kabupaten Tegal. 2017. Data Penduduk Kabupaten Tegal Tahun 2017. Diunduh dari laman http://tegalkab.bps.go.id pada tanggal 26 Januari 2018.

[2] BPS Kabupaten Tegal. 2017. Data Penduduk Kabupaten Tegal Tahun 2017. Diunduh dari laman http://tegalkab.bps.go.id pada tanggal 26 Januari 2018.

[3] Austin, J.L., How to Do Things with Words. Oxford University Press, New York(1962)

[4] Searle, J.R. , The classification of illocutionary acts, Language in Society 5, 1 - 24 (1976)

[5] Aijmer, Karin. 1996. Conversational Routines in English: Convention and CreativityLondon: Longman.

[6] Trosborg, Anna, Interlanguage Pragmatics: Request, Complaints, and Apologies, Mouton de Gruyter (1994)

[7] Baba, T dan Lian, L.C. 'Differences between The Chinese and Japanese Request Expression'. Journal of Hokkaido University of Education. 42(1).(1992)

[8] Felix-Brasdefer, J Cesar.. 'Indirectness and Politeness in Mexican Requests'. Dalam David Eddington. Selected Proceedings of the 7th Hispanic Linguistics Symposium. 6678. Somervilla, MA : Cascadilla Proceeding Project(2005)

[9] Mualimin. "Kesantunan Direktif dalam Korespondensi Bisnis berbahasa Inggris di Kalangan Penutur Bahasa Indonesia”, Tesis. Depok: Pascasarjana UI (2002)

[10] Gunarwan, Asim.'Realisasi Tindak Tutur Pengancam Muka di Kalangan Orang Jawa: Cerminan Nilai Budaya" dalam Gunarwan. Pragmatik: Teori dan Kajian Nusantara. Jakarta : Penerbit Universitas Atma Jaya. (2007)

[11] Soedjito. et. al. 1986. Pemakaian Bahasa Jawa di Daerah Pesisir Utara Jawa Timur Bagian Sempit. Jakarta : Pusat Pembinaan dan Pengembangan Bahasa. Depdikbud.

[12] Suwadji dkk. (1981). Dialek Bahasa Jawa di Pesisir Utara Jawa Tengah (Tegal dan Sekitarnya) Jakarta: Depdikbud

[13] Paina. "Tindak Tutur Komisif Bahasa Jawa” Disertasi. Yogyakarta: Universitas Gadjah Mada. (2010)

[14] Setiawan, Lanang, Tegal Sumbu Pendek, Media Tegal Tegal, Tegal (2015)

[15] Setiawan, S and Atik, Tegal Melawan, Media Tegal Tegal, Tegal (2016)

[16] Setiawan, Lanang, Ndoro Binyak, Media Tegal Tegal, Tegal (2017) 